\title{
The Sharing Economy and Social Capital: The Fictional Expectations of Sociality in a Time Bank
}

\author{
M. SHMIDT*
}

\begin{abstract}
*Mayya Shmidt - PhD Candidate, Department of Sociology, Uppsala University. Address: Thunbergsvägen 3H, 75126 Uppsala, Sweden. E-mail: mayya.shmidt@soc.uu.se

Citation: Shmidt M. (2021) The Sharing Economy and Social Capital: The Fictional Expectations of Sociality in a Time Bank. Mir Rossii, vol. 30, no 4, pp. 128-155. DOI: $10.17323 / 1811-038 X-2021-30-4-128-155$
\end{abstract}

This article looks at time banking - a system of exchange in which people trade services with one another using time instead of money as currency. Time banking is framed from a social work perspective as a social innovation that contributes to poverty alleviation and increasing inclusion. However, most such organizations fail to institutionalize as care providers and fail within the first three years. In this paper, I discuss a rare success story-a time bank in Nizhny Novgorod, the fourth largest city in Russia-which has been functioning for over 15 years and positioned itself as a non-charitable organization.

I engage with sharing economy studies - a growing but ambiguous field - to explain the success of the time bank in Nizhny Novgorod. Research in the sharing economy has mostly concentrated on two extreme cases: business-to-customer operations or grassroots communities practicing radical alternatives to market exchange. The case studies have been united by an assumption that sharing economy organizations would generate social capital. However, there has been limited evidence to support this claim. In this article, I aim to test this hypothesis and explore whether the informal networks, norms of reciprocity and trust that are fostered among members of the Nizhny Novgorod time bank are the factors that explain the sustainability of this association.

The study is informed by 22 in-depth interviews with the gatekeepers and members of this community. In the interviews, I paid attention to the socio-demographic characteristics of the participants and the structure of their social capital; the characteristics of the mode of exchange practiced in the community (the volume, direction, and range of services, the relatedness to professional activities and other spheres of life); their value set and worldview (egalitarianism, altruism, justice); and indicators of generalized trust.

Results revealed that time bankers do not tend to create strong and sustainable relationships outside of the framework of the exchange. I put forward the following explanatory hypothesis: 
the calculativeness of time bankers, the market-driven valuations of 'egalitarian'service exchange and a unilateral attitude to the exchange are in conflict with a longing for Gemeinschaft-a community with strong bonding interdependence based on the norms of mutuality. This association failed to provide the conditions for generalized trust to emerge. The attempt to simultaneously create a tightly bonded community, but still answer the needs of the digital age resulted in a pastiche of a sharing economy platform.

Beyond the case at hand, this study theorizes the rhetoric and reality of the sharing economy by summarizing the grounds for the expectations of generating social capital and explains why certain expectations could not be met.

Keywords: time banking, sharing economy, non-for-profit associations, social capital, trust, brokerage

\section{Introduction}

This paper looks at time banking - a system of exchange in which people trade services with one another. Within a time bank, money does not exchange hands, but a time-based currency - credits earned by providing services and spent by receiving them-does. The bedrock principle of time banking is that the value of offers is equal and measured in hours of service. The currency unit traded is valued at 'an hour's worth of any person's labor'. This egalitarian accounting system and the democratic principles of governance practiced in such organizations became programmatic for the founders of time banks (TB) all over the world thanks to Cahn's works (see for example [Cahn, Rowe 1992]). The term 'time dollar' was coined by him and has been used in the US. Prior to the widespread diffusion of the Internet, time banks operated as local communities of mutual assistance: they were tied to existing institutions (schools, hospitals, churches, social services, etc.), and targeted vulnerable populations [Collom 2008; Seyfang, Smith 2002]. They have been replaced by digital platforms (such as TimeRepublik) that have enabled time banking to scale up [Del Moral, Pais 2015; Arcidiacono, Podda 2017].

Time banking has been studied in the complementary currencies and LETS (Local exchange trade schemes) literatures. LETS have been gaining popularity in Europe in response to the political instability of the 1990s in Italy [Del Moral, Pais 2015], the transformation of the social services system in the UK in the 1980s [William et al. 2003] and the Greek debt crisis that began in 2010 [Henley 2012]. In Russia, the same practices were found in Irkutsk, where in 2007 a barter club " 100 friends" was organized. This local trade system used coupons for mutual credit [Mitusov 2013]. In 2013, the Supreme Court of Bashkiria recognized the legality of "shaimuratiki" - the local currency of the city of Shaimuratovo [Zykova 2013]. Both were created to compensate for imperfections in the local economy. However, there are inevitable differences between the principles of LETS and time banking. LETS emphasizes economic exchange, while TB are promoted as a social exchange system [Seyfang 2004]. The former uses an alternative currency that reflects the prevalent market valuation of services, while the latter is built upon the equality of a time-based currency.

The present study is on the Nizhny Novgorod Time Bank (NNTB), an organization that has existed since 2006 on the basis of the Nizhny Novgorod Volunteer Service. 
NNTB's work is based on the 'purist' principles formulated by Cahn - an egalitarian exchange using a time-based currency. The organization also has a mixed territorialdigital structure [Del Moral, Pais 2015]. This case contrasts the framing of time banking in a social work perspective, which describes time banking as a social innovation focused on local community-building, especially in disadvantaged areas and targeted at vulnerable populations [North 2003; Seyfang 2004; Dittmer 2013]. The popularity of such initiatives should increase during economic turmoil [Weaver et al. 2016], as they are supposed to aid poverty alleviation, overcoming social exclusion and alienation, and to compensate for the imperfections of social provisions. The primary message of NNTB is that it is a non-charitable organization. Quite the opposite, it is aimed at being an autonomous from social care provision and at overcoming hierarchical relations between giver-receiver by providing a platform for the peer-to-peer exchange of services. About $70 \%$ of TB collapse within the first 3 years [Weaver et al. 2016], while the Nizhny Novgorod case is a rare success story, which adds to the understanding of how time banking as a type of exchange institutionalizes and reproduces. Using NNTB as a case study allows us to retrospectively trace how this system of exchange evolved over 15 years and to make explanatory hypotheses of why other attempts (strictly territorial or strictly digital) have failed.

As an alternative economic activity, time banking has received some attention in studies of the sharing economy. Time banking is positioned as a part of the sharing economy- "for-profit and non-profit peer-to-peer sites serving individuals in offline exchanges" [Schor 2020]. The sharing economy emerged in the US in the aftermath of the Great Recession and the Occupy Wall St movement [Horowitz 2011], as a need to "do more with less". Despite the fact that sharing is as old as civilization itself [Widlok 2016], the new decentralized form of online interaction became visible after Laurence Lessig coined the term in his "Remix" to contrast the nonmonetary sharing economy with the commercial economy [Lessig 2008]. The same year Airbnb - the short rental online marketplace - was founded and soon became one of the three (together with $\mathrm{Uber}^{1}$ and Lyft) biggest players identified by many as the core of sharing economy based on the use of idle assets by private individuals [Frenken, Schor 2017]. The core idea of the sharing economy is a peer-to-peer market in which durable assets with excess capacity are rented out on a temporary basis [Schor 2020] usually via web-based platforms or mobile applications. This field is conventionally defined as including polar enterprises: business-as-usual and radical alternatives to market exchange. Time banking is an example of a not-for-profit peer-to-peer service exchange initiative (a for-profit analogue in Russia would be, for example, YouDo.com). Within this site, exchange is carried out between two individuals, who enact an asynchronous dual role as provider and receiver of services, and an organization acts as a mediator. Skills and time are the objects of exchange, the benefits from such exchange are social and economic [Valor, Papaoikonomou 2020]. While the large commercial players have attracted most attention, from the beginning the sharing economy included not-for-profits offering a wide range of distributional agreements: from food and clothing swaps to rental, gifting and loaning sites for consumables, repair and DIY cafes, makerspaces, service exchange or errand sites, such as TB. The not-for-profits have been integral to the emergence

Unlike other players, Uber has always rejected the rhetoric of sharing, yet the company is commonly addressed as a pioneer of the sharing economy [Ravenelle 2018]. 
and development of the sector. These mostly community-based initiatives helped to legitimize the utopian promise of Silicon Valley corporations to create economic, social, and environmental benefits [Cockayne 2016; Martin 2016; Schor 2014; Schor 2020]. Sharing economy studies speak to these claims; there is a consensus that communitybuilding is a primary goal of participation in sharing economy organizations. In this vein, TB have been defined as community building initiatives "which enable people to exchange goods and services using time as money" [Seyfang 2004, p. 1], and "alternative market with the hopes of empowering the economically marginalized and building social capital" [Collom 2011, p. 144]. The functions of time banking described in the literature include supporting local residents, keeping "money" in the community, thus strengthening the local economy [Collom 2011], and fostering community relations and building social capital [Seyfang 2001; Seyfang 2009]. There is, however, limited discussion addressing the claims of the sharing economy creating social benefits.

The theoretical underpinnings of this article are found in social capital theories used to account for the findings of an interview-based study of a TB in Nizhny Novgorogd, Russia's $4^{\text {th }}$ largest city. The paper positions time banking within sharing economy studies, and by integrating previous work in this field by authors who explicitly engage with the concept of sharing, it tests the hypothesis of whether the sharing economy contributes to the generation of social capital.

To this end, this paper addresses the following research question: Does generation of social capital have an impact on building a robust community in the sharing economy?

This article offers a preliminary analysis of failed community-building attempts in the NNTB, which has been successfully functioning for over 15 years. The results reveal that it failed to generate social capital in form of durable networks, norms of reciprocity or generalized trust, while creating human capital in form of valuable skills, habits and individual traits which enabled the professional development of members. This allowed the formulation of an extended hypothesis about the inability of some sharing organizations to generate social capital and fulfill the expectations imposed on them due to the tensions arising between top-down ideological extremes and practice. The paper concludes with a discussion of the main implications of this argument.

\section{The sharing economy and community-building: rhetoric and reality}

Arvidsson argues that the sharing economy represents a peculiar kind of re-embeddedness of the economy based on digital platforms, which combines market and social logic, and which is characterized by "the coexistence of instrumental action oriented to exchange and market, and virtuous action oriented to relationship and community" [Arvidsson 2018, p. 290]. This duality fascinates most of the research in the field. The notion became associated with tensions between market order (platform capitalism driven by for-profit firms), and non-market order (collaborative commons fostering social cohesion). Part of the confusion is that the definition of the sharing economy has migrated from being a solely grassroots phenomenon connected to anticonsumerist social movements to being predominantly identified with Silicon Valley-backed ventures which have become more and more successful. Sharing practices retain strong normative connotations - an idealistic and inclusive view of a community 
[Cockayne 2016] "essentially altruistic, pro-social, and nonreciprocal, yet predicated too on private ownership and the possibility of capitalist exchange" [Benkler 2004].

A mainstay of the sharing discourse is that it will build strong social ties among strangers. By reviewing the literature speaking to this claim [Albinsson, Perera 2012; Eckhardt, Bardhi 2016; Harvey et al. 2018; McArthur 2015; Ozanne, Ballantine 2010], I suggest that the persistent "sharing fiction" is built on a vision of sharing as a Gemeinschaft practice, a community that creates strong networks of interdependence. These communities are tightly knit and manage to govern common resources "by creating shared rules and norms available in a tight relational network with expectations of reciprocity. Individuals communicate and interact with each other in a localized physical setting [so that they develop] shared norms and patterns of reciprocity" ([Ostrom 1990, p. 184] as cited in [Arvidsson 2018]). Gemeinschaft-a tightly bounded group of people who live in a close proximity, whose relationships are based on mutuality and caring [Toennies (1887) 1957] is persistently held up as an ideal to support the sharing fiction. The origin of such attitudes are rooted in interdependence and trust. In the same vein, Putnam theorized community as based on civic engagement, a sense of belonging, and contribution [Putnam 2000]. Historically people tended to share inside their close social networks of trusted individuals. People were closer physically and socially - early examples of sharing signifies highly localized collaborative and co-operative behavior. Sharing is as old as civilization itself, proven by the literature in anthropology, psychology and behavioral sciences, revolving around the social practices of sharing [Belk 2017; Davies et al. 2017; Kovács et al. 2017; Widlok 2016] Prototypes of sharing are found within kinship-based groups and characterized as "sharing in", an empathetic caring behavior helping to create and reinforce social bonds and a feeling of commonality [Belk 2017; Belk 2010]. Sharing may have played an important role in shaping human history, social organization, and cooperative behavior [Kaplan et al. 2005]. Anthropological studies of hunter-gatherer societies make it clear that sharing was constitutive of social relations, a social practice of distribution governed by social norms [Pryor, Graburn 1980], and the most universal form of economic action, distinct from the narrower notion of reciprocity [Price 1975].

Pre-modern forms of sharing were distinguished by: (1) having roots in the moral economy, (2) sharing meant "to divide into parts", (3) sharing food and communal infrastructure; (4) being based on kinship groups, and (5) most importantly, being social and altruistic. Modern forms of sharing are, on the contrary, networked, existing in a market economy, having at least three meanings (the introduction of the sharing of both tangible and intangible objects, emotional states and even "fuzzy" objects [John 2013] such as "life, world, belief"), relying heavily on information and communication technologies, practicing exchange irrespective of the social structure of the group or the structure of relations between members of the group. Modern sharing is criticized as being behavior driven by self-interest, as Morozov puts it "the sharing economy amplifies the worst excesses of the dominant economic model: it is neoliberalism on steroids" [Morozov 2013]. The logic is that digital platforms, on which sharing is organized, involve the pursuit of economic profits, rather than solidarity. As the sharing economy became a system commodifying everyday life, it turns people into neoliberal subjects crowding out altruistic sharing [Schor, Cansoy 2019]. As Arvidsson puts it, "the sharing economy is situated in an area of economic action where the logic 
of market exchange coexists with a logic of virtue anchored in communal social relations [...] with the desire to create and reaffirm social relations; to contribute to a common cause; [...] practice and promote a number of virtues" [Arvidsson 2018, p. 290]. Russel Belk distinguished between "true" and "pseudo" sharing. Belk defines sharing as "the act and process of distributing what is ours to others for their use as well as the act and process of receiving something from others for our use" [Belk 2007]. He further distinguishes between "sharing in" and "sharing out": "Sharing out, as seen in dividing a resource among discrete economic interests, preserves the self/other boundary and does not involve expanding the sphere of aggregate extended self beyond the family. But sharing in expands the sphere of extended self by expanding the domain of common property" [Belk 2010, p. 726]. This points to tensions between the moral and economic implications (sharing within a small kinship-based community) and the market economy. Much of what is called the sharing economy today is pseudo-sharing, according to Belk's description of what sharing implies, as the sharing economy is not aimed at the creation of social bonds, but is distinguished by "the presence of profit motives, the absence of feelings of community, and expectations of reciprocity" [Belk 2014, p. 7]. Sharing has been associated with activity of the "home, rather than the exterior worlds of work and the market" [Belk 2010, p. 716]. Prototypes of sharing are found within kinshipbased groups and characterized as "sharing in", an empathetic caring behavior helping to create and reinforce social bonds and a feeling of commonality [Belk 2017; Belk 2010].

Why do we expect the sharing economy to create social bonds at all? Three main discursive threads build up the sharing fiction:

1) The sharing economy advocates exploiting the "innate human capacity to share" [Bird-David 2019, p. 1] and describes human societies as naturally inclined to achieve cooperation, trust and togetherness. It does so by referring to anthropological studies of sharing in hunter-gatherer societies and arguing that hunter-gatherers display "prototypical sharing [...] in the simplest forms of human social organizations" ([Woodburn 1998, p. 63] as cited in [Bird-David 2019) and by referring to prehistorical societies a la Kropotkin and his concept of mutual aid ([Kropotkin 1902] as cited in [John 2017, p. 81]).

2) The second thread is built on the techno-exceptionalist idea that the digital revolution opened up an abundance of possibility to interact with strangers and gave way to "sharing turn" [Grassmuck 2012]. Often, "stranger sharing" [Schor 2014] takes place on digital platforms, extending the circle of individuals who get to share. This brings increases participation in sharing as it became much easier to reach out to different populations and create bridging social capital. Sharing economy transactions are based on the idea that strangers trust each other. Technically, platforms mitigate risks by crowdsourcing reputational information from its users, thus fostering trust between strangers and reducing free riding and non-cooperation. Not-for-profit sharing economy sites, however, aim to sustain social and sustainable goals, and build up trust in a sense of community, participants' intrinsic motivation, social norms and values [Ter Huurne et al. 2015, p. 495]. The act of altruistic sharing leaves traces in the digital space. As platforms crowdsource information about past transactions, and form networks in which reputations are posted, trustworthiness is promoted by monitoring each other in the network.

3) The third line of reasoning is grounded in the idea that the sharing economy generates social capital as means of rule enforcement and increases security by "sowing 
seeds of reciprocal obligations" [Belk 2010, p. 715]. Sharing economy sites promote cooperation, collaboration, trust, etc., while issuing sanctions for non-compliance (by, for example, excluding opportunistic members and free riders). The shared expectations of generalized reciprocity are supposed to bond members together. The logic is that by making contributions to the network, you will be paid back by the benefits of being a part of an "imagined community" and can make use of communal resources when needed. These expectations are of course driven by the strong normative conformity and ideological commitment with the stated goals of participation.

Social capital "refers to the basic raw material of civil society" [Onyx, Bullen 2000, p. 24]. At the most general level, the concept of social capital includes a relationship element (concrete social ties) and a resource element (e.g. trust) at the individual and collective level. Although conceptualizations vary between authors and disciplines (for example, social capital theory has been widely used in the democratic political and the economic development literatures), I follow Putnam in that social capital provides a passage from micro-level analysis of how interpersonal relationships produce social cohesion to the macro-level analysis of the effect that social capital has on social connectedness in general. Putnam considered social capital and community to be "conceptual cousins" ([Putnam 2000, p. 21] as cited in [Castiglione et al. 2008]). Onyx and Bullen discussed social capital in terms of participation in networks, reciprocity, trust, social norms, the commons, and social agency [Onyx, Bullen 2000]. Castiglione et al. discussed three broad meanings of social capital accounting for the role it plays in promoting social cohesion [Castiglione 2008, p. 557]:

1) resources provided by being connected to a social network (information, coordination and cooperation, personal support, ability to sustain social norms);

2) attitudes of social cooperation fostered by being connected to a social network (trust, generalized reciprocity);

3 ) the moral capacity to internalize virtues of the common good (civicness).

Social capital, defined by its function of being a resource for actors, appeared in Coleman's theory [Coleman 1988]. He defined social capital as a resource for action and described how strong ties shape obligations and expectations, information channels, social norms, informal social control, and trust. Drawing on Coleman's theory, Putnam defined social capital as "those features of social organization, such as trust, norms and networks that can improve the efficiency of society by facilitating coordinated actions" [Putnam 1993, p. 35] and as "features of social life-networks, norms and trust - that enable participants to act together more effectively to pursue shared objectives" [Putnam 1995, pp. 664-665]. He further discusses two types of social capital-bonding and bridging. The former implies the relationships that benefit a narrow circle of people which may be to the detriment of society, while the latter assumes interactions that are beneficial to society as a whole. Fukuyama conceptualized social capital primarily in terms of generalized trust and defined it as "the expectation that arises within a community of regular, honest and cooperative behavior, based on commonly shared norms, on the part of other members of that community [Fukuyama 1995]. Those norms can be about deep "value" questions like the nature of God or justice, but they also encompass secular norms like professional standards and codes of behavior" [Fukuyama 1995, p. 26].

The next section demonstrates the conceptualization of social capital applied to the further analysis of the community-building potential of NNTB. 


\section{Methods}

The empirical study is informed by 22 in-depth interviews which were recorded and transcribed. Maximum variation in the sample maximized the diversity of cases to answer the research question. The recruited participants had varying degrees of involvement in the community (active members and newcomers) and varying degrees of awareness of community life (members and gatekeepers). The analysis draws on extended interviews with an expert on local currencies and the first trustee of the TB. All names were anonymized. The participants were recruited using snowball sampling, the entry point was NNTB's website.

There were 5 males and 17 females, ages varied from 17 to 50 (which refutes the hypothesis of the need for a bank exclusively for older participants as in [Collom 2008]). The demographic characteristics of the sample are representative of the group. There was no screen for the length of participation, but the participants had from 3 to 15 years of experience on the site. The duration of the interviews ranged from 45 to 90 minutes, and the conversations took place via Zoom.

I used a semi-structured interview guide which set the thematic structure but allowed me to build a narrative in individual interviews. The guide paid specific attention to the following narratives:

1) the socio-demographic characteristics of interviewees and the structure of their social capital;

2) the characteristics of the mode of exchange practiced in the community (volume, direction, repertoire of services, relatedness to professional activities and other spheres of life);

3) interviewees' value set and worldview (egalitarianism, altruism, justice);

4) trust.

Transcripts of the interviews were coded by line-by-line coding and prior conceptualization. Thematic analysis was applied to reveal analytical categories. This process represented a movement from the particular to the general, and from analytical memos to concepts of a larger significance.

\section{Findings}

I turn now to discuss the case of NNTB emphasizing the community-building practices I observed there and evidence of attempts to generate social capital. Despite the stated egalitarian claims and the intended inclusive participation, the results revealed that members are far from establishing a sustainable community driven by the desire to contribute to the common cause. Findings point to the calculativeness and self-interest in participation in the TB, the hypothesis of the promotion of a number of virtues such as autonomy, civic participation, cooperation, desire to reaffirm social relations found no support. Members of NNTB were successful in generating human capital in form of valuable skills. Did it lead to the development of bonding ties and improving social cohesion? There was not enough evidence to suggest that time bankers create strong and sustainable relationships outside of the framework of exchange. I put forward 
the following explanatory hypothesis: the calculativeness of time bankers, market-driven valuations of 'egalitarian' service exchange and a unilateral attitude to the exchange stand in conflict with longing for Gemeinschaft-type of community with strong bonding interdependence, based on the norms of mutuality. This association failed to provide the conditions for generalized trust to emerge. The attempt to simultaneously create a tightly bonded community, but still answer the needs of the digital age resulted in a pastiche of a sharing economy platform. These findings challenge the claims the organization makes about egalitarianism and raise questions about how the fulfillment of the social goals of participation varies across sharing economy sites.

\section{Organizing the Time Bank - a success story?}

NNTB was founded in 2006 as a project of the Nizhny Novgorod Volunteer Service. The project owed its launch to a local entrepreneur who imported the idea from the Rushey Green Time Bank in London and sponsored the founding of a similar association in his hometown. The idea was very simple. A bedrock principle of time banking is that it has an egalitarian structure-it assigns equal value for each person's time and skills. It means that value is not created the same way as through commodity exchange; for every hour you spend providing service to someone, you are entitled to an hour of credit. The 'hour-credits' that can be 'spent' on ordering a service from another member (or, 'client', as they call themselves). Obtaining a better variety of services is a frequent concern in time banking [Collom 2008]. The importance of a range of market services for a time banking scheme to become successful was echoed in NNTB as well. The range of services offered in NNTB is comprehensive, but can be reduced to several categories:

1) household services (varying from flower watering to electrics and plumbing);

2) informal education and training (languages, tutoring in school subjects, music);

3 ) the creation and fabrication of products (tailoring, baking, clothing repair);

4) healthcare and beauty;

5) non-standard services that have limited supply on the market (for example, graphology, tutoring in Old Slavonic lettering, etc.)

There is a large list of prohibited services, mainly related to the physical well-being of members. This quotation from an interview with one of the members exemplifies the working of the time banking mechanism:

I provided everything related to needlework and tailoring. I ran a few errands. I helped to organize an exhibition of TB clients'works. That is, all the participants of the time bank who do something tangible: bake, sew, make, they brought their work. These were sold for 'hours'. That is, if you have, for example, 20 hours on your account, and here is some knitted blouse worth 10 hours, you can buy it for 10 hours. I then baked something; it was sold in pieces. For each piece, I put a price tag on half an hour or so. Most often, people honestly reckon on how much time they spent. Well, you can add a little bit, but nevertheless, people who exhibited their goods, they earned hours. Most of the time, I earned 'hours'doing such things like tailoring and repairing. And I ordered services, most often, anything renovationrelated. We were just starting renovation and there were bags full of cement to carry up our 
staircase. Once I did not know how to move the furniture in the kitchen-the refrigerator, stove, table. And I called some guys and asked, "Who can help me? You will move, I will watch." And people agreed to do this nonsense and moved the furniture.

This mechanism is an instance of a chain-generalized exchange system that requires indirect and multilateral exchange from users. In some sharing contexts users have the option of being either the provider or the consumer, (such as for example, the sharing of consumables), while in TB, members are explicitly required to take on both roles in order to ensure the continuity of exchange. If a member takes a role of receiver, sooner or later their 'hour-credit' balance will fall to zero, and they will be forced to leave the exchange circuit or start providing services to earn 'hours'. If members only provide services, their balance will increase until there are no more people left to trade with. In this case, the provider has the same choice: to either leave the time bank or change roles. Exchange is facilitated online and offline. The spaces available for NNTB members are a physical office located in the center of Nizhny Novgorod, and a digital platform launched in 2009 to reduce administration to minimum and to allow members to contact and share on their own. The digital space is a noticeboard-like website where members can post and reply to offerings and monitor ratings and reviews others leave. In practice, the communication there is limited as the website is rarely updated. The preferred type of communication is offline - through a broker who matches the supply and demand for services. Previous studies which discussed TB which adopted Cahn's ideas described the primary role of a broker (often a paid employee) as a facilitator of exchanges between private individuals. Platforms and software in such organizations have the main role of helping the broker to manage exchanges and collect data about the members rather than serving as a connective platform for members.

Communications mediated by a broker work in the following manner. A client requests a service, the broker (or, coordinator, to use the local parlance) finds the availability of potential contractors through personal calls and makes an offer. The broker selects a number of contractors from the database, basing the selection on their ideas about the match. The client that contacts the contractor on their own to negotiate the details and secure the payment in 'hours'. After performing the service, both return to the coordinator in order to close the deal, and to report how many hours should be debited from one account and credited to the other. They report the time of service provision. In practice, many services are accompanied with unaccounted time for preparation and for a short interaction after the service is finished. A paid broker who oversees and sustains operations is a key gatekeeper in the community. Having a broker, however, makes TB dependent on external funding to cover brokers' wages. Funds secured by NNTB allowed them to keep a maximum of 3 brokers at a time, which imposed constraints on participation. Each broker had a capacity of 250-300 members and experienced difficulty in sustaining a network once that threshold was reached. The number of members averaged never exceeded 700 registered participants at a time, the peak was in 2011, when NNTB registered 2,000 participants, during the less successful years, there were 200-300 active members.

Compared to the majority of time banks, which fail within the first three years, we may call NNTB a success story, as it managed to get a robust economy and trading system that has been working for over 15 years. The timeline below (see Table 1) shows 


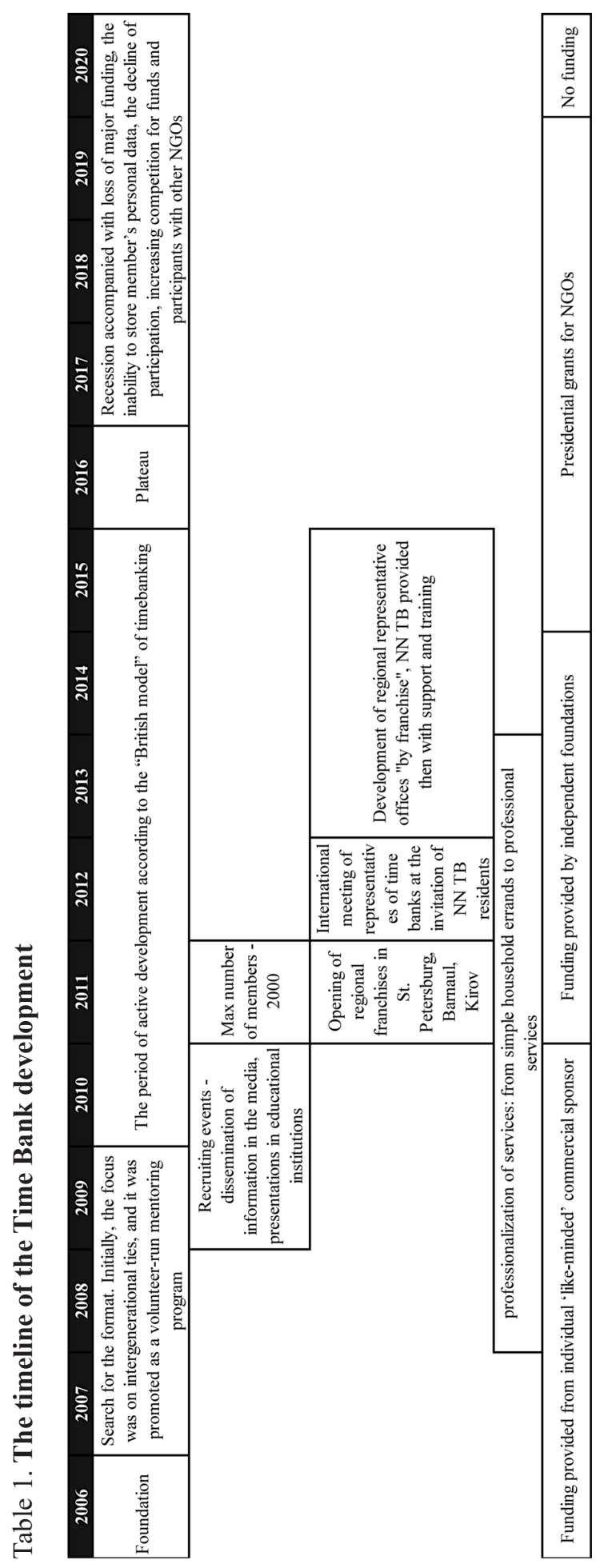


that NNTB has demonstrated great continuity over the years of operation. From the standpoint of the organizers, the success of their organization was mostly determined by stable funding. Nevertheless, as the findings show, funding cannot solely determine the sustainability of TB. While funds are important to hire brokers, who manage the exchanges between participants, it cannot guarantee success in terms of the number of exchanges in hours.

What kept participants returning to NNTB was having the ability to use it as a complementary financial instrument. Participants were not dependent on the provision of services from the TB. The key to success from the standpoint of participants was not to view NNTB as a survival mechanism. Research shows that poverty and inequality do not contribute to the success of time banks despite the fact that a key objective of time banking is to help unemployed, impoverished, or marginalized individuals [Gawthorpe 2017]. Collom found that poverty negatively affects the number of hours exchanged, as impoverished but employed individuals might be deprived of time to be involved in time banking [Collom 2008]. The majority of participants in NNTB were middle-aged, educated and self-employed women who either had flexible working hours or a sustainable work-life balance which left them a sufficient amount of time to spend on participation in time banking. Furthermore, they were not dependent on those services. The available time of the participants could have contributed to the growth of human capital in the form of valuable and marketable skills. In the following section, I show that even though NNTB became a success in terms of providing a platform for improving human capital, it failed to provide conditions for social capital to emerge. The divergence between the ideological commitments of time bankers and their practices led to further atomization and alienation.

\section{Ideology and practice}

The period of active development began when NNTB adopted the original Cahn model. The main ideas they built upon are "core economy" and "co-production" [Cahn 2000], highlighting how the non-monetary exchange of services can contribute to the wellbeing of community members, and thus respond to the "need of redefining the economy".

"Time Dollars [...] are designed to rebuild a fundamentally different economy, the economy of home, family, neighborhood and community. [...] Home, family, and neighborhood are not an alternative economy. They are the CORE Economy" [Cahn 2000, p. 2]. Cahn argued that marketization has seriously damaged this core economy, which echoes Polanyi's seminal work "The Great Transformation". Time banking could bring economic activity back into communities and de-commodify it, re-balancing the economy by reducing the dependence on markets and state welfare while increasing intra-communal cohesion. This logic emphasizes the egalitarian and communitarian ideology of TB organizers vis a vis capitalist markets, embedded in a view of actors as 'homo economicus': calculative and self-interested utility-maximizers.

Organizers of NNTB and most of the participants adhere to this rhetoric and expressed a longing for community. Intended outcomes of participation in time banking were stated by organisers as follows: building community, skills (including sociability) 
and social networks; improved intergenerational relations; increased social inclusion for typically marginalized groups; increased access to public services.

I will now turn to an assessment of these claims. Further analysis shows that time bankers could generate human capital in form of a stock of valuable skills, habits and the individual traits which developed their professional skills. They however receive little or no recognition of services that "a pure market system devaluates". The paradox is that, apparently, the ideological alignment with the stated outcomes of participation is very high across members. In the interviews, participants repeated Cahn's promises almost verbatim while the transaction patterns they follow contradict their egalitarian stance and tell a radically different story.

\section{Calculativeness vs communitarianism}

Nikolay vocalized the ideological alignment with the virtues of solidarity by a comparison with mutual benefit funds - "we pool our talents together to help out a peer in need". Regina and Igor showed their adherence to the practice of tithing, paying a contribution to a religious organization as an indicator of justice, mercy and faithfulness. Nevertheless, these members quickly realized that by offering services to others they are not volunteering, but earning "hours", and this time can be included as an additional currency in their budgets. Having additional currency at their disposal opened up new opportunities, as Regina told me later during the interview:

People have credit cards in their wallets. Having two cards is much more useful than possessing one - each may have different interest rates, or you may have ruble and dollar accounts. It's the same here-I have rubles, and I have "hours"- and I know what I possess, what I can buy, and what I can order free of charge.

I noticed that time bankers used the additional currency they possess when they budgeted for multi-composite events, such as renovations, anniversaries, weddings, concerts, and even pre-university training. Time-based currency is a relatively easily accumulated currency, compared to money. To save up enough hours to pay for the services, members activated a limited set of saving strategies, including organizing master classes and fairs for other TB members (in this case, the leader receives an hour payment from each participant), and giving an individual course in any subject which consists of several classes (each class would be some "hours" worth).

I said that I'm going to pay for the lessons. She actively objected. She told me that she needs to earn hours.

Regina, a professional seamstress, evaluated expenditures in "hours" against the benchmark of her earnings in money. This was specifically the case for other members 
who knew the "price" of their hour-professionals who get paid on an hourly basis. The calculus they made was the following: first you need to account for time spent on providing services (and hours earned) and compare it to the time lost in the labor market. Step two was to account for wages lost compared to that amount of time. Having in mind the specific needs one has to cover (for example, any reparation service) and the costs of these needs, step three was to compare monetary expenditures and time expenditures. Finally, a decision was made on whether it was more profitable to lose in earnings but get services done which otherwise cost more than the losses. As Regina mentioned, "[NNTB] is a space for people who value their time". This expression surely takes on a new meaning in the context of translations from time to money which time bankers make.

Tatyana is a professional confectioner. Her clients can find the services she offers on her personal page on a popular Russian social networking site. Surprisingly, the page showcases dozens of photographs depicturing the cakes she baked for TB peers. Her story showed us that there are participants in NNTB who through delivering services for peers get valuable and marketable skills and build up their CVs, which might be helpful in finding employment or starting their own enterprises. Tatyana not only practiced in NNTB, but she also made active use of the hours she earned.

I made wedding cakes, birthday cakes. My husband is a maintenance specialist, he also helped people. So we went together to someone's dacha to hang wallpaper. My eldest son, when he finished school, he was studying for university admission exams. He took lessons in mathematics and physics. He successfully completed them and was admitted thanks to his studies. My husband celebrated his anniversary. I had 8 people involved from the time bank. I had two dresses made for this event. Then we had a cook, a bartender, a photographer, a graphic designer, an artist. Musical numbers. I took vocal lessons, too, in [NNTB] for this event. Full pot, actually. We even had a dancer from the time bank.

While longing for community, participants remained rational about their transactions. The ideology of time banking assumes greater independence from the market-based provision of services and increased access to public services. Participants in my study were not deprived of public services or state welfare. Assessing this claim is outside of the scope of my research, however, the data suggests that time bankers fall into greater dependence on market-based provisioning, both as consumers of valuable services, and as providers preparing to enter the market with improved skills (building up human capital).

\section{Shallow interactions vs improved social ties}

In this section, I turn to the question of whether the human capital generated is converted into social capital in form of informal networks, norms of reciprocity and trust fostered among members of NNTB. The results suggest the instrumentality of ties and reveal shallow interactions between time bankers which do not lead to deeper sociality. 
Strengthening ties among members and encouraging community development is stated as an intended outcome of time banking. However, none of the participants in this study formed new friends or acquired valuable contacts through participation in NNTB. Communication rarely went beyond the exchange of services as members showed little or no interest in altering social relations with alternative modes of exchange. The findings suggest that calculative attitudes and issues with building interpersonal trust made it harder to establish strong interpersonal ties.

As I explained in the previous section, many of the members of NNTB treated this community as an alternative savings plan and were mostly motivated to participate in paid tasks. Altruistic participants, who showed an ideological alignment with claims of the common good and followed them by delivering services without demanding anything in return, were crowded out as the time banking exchange mechanism is built upon the idea that members enact the double role of providers and receivers.

If it turns out that a person only needs services, but is not ready to provide services, or, on the contrary, the person intends to help others, but does not want anything in return, they are invited to contact the volunteer organizations of the city and are given their contact information (from the broker's handbook).

Furthermore, in practice, time bank organizers actively downplayed the forms of altruism and volunteerism that demand direct help to hide the embedded inequalities between providers and receivers. Organizers emphasized egalitarian imperatives instead and defined the scope of their organization as specifically distinct from volunteer organizations. This led to further atomization of participants who took on this rhetoric, stating their interest in trade rather than in altruism.

I personally am not attracted to volunteering in its purest form. You know, time, effort, travel. I'm too old to be running around the city like a young man for nothing.

From the beginning, NNTB focused on fostering intergenerational ties and promoted its services as a mentorship program. The idea, which failed in the short run, was to connect two unemployed populations - the elderly and students. According to the data collected by the organizers, in the long run NNTB sparked the interest of the middle-aged population-employed professionals, mostly women. Although the origins and models of time banking vary across time and space, they do have one common feature-women seem to be overrepresented. [Boyle 2014; Del Moral-Espin 2013; Valor, Papaoikonomou 2020]. Due to age homogeneity, intergenerational interactions remained in the minority.

I'm a tech-savvy person, and most of the time bankers are humanities-minded. And mostly women, pensioners. What common interests can we have? I was 36, and theywere 60 years old. 


\section{Brokerage and trust}

As mentioned, exchanges in TBs have been fully controlled by brokers-paid members of staff who match counterparts, oversee trading and gathered reputational information about participants. Brokers act as structural links [Burt 2009] collecting and transferring information between unconnected individuals, thus having control over the network. I assume that effective brokerage discouraged members from creating interpersonal ties. Furthermore, brokerage discourages participants from filling the structural holes by crowdsourcing information about themselves and their past trading behavior on a web-platform. It was more convenient to delegate matching and overseeing to a broker, who was a trusted individual. Time bankers trusted brokers because they were seen as the source of full information, while the web platform was viewed as something estranged and incomplete. Time bankers' techno-pessimism can be explained by the fact that they overcame the risks of trading with strangers by appealing to more archaic ways of establishing trust (interpersonal connections), rather than by appealing to novel, impersonal means (platformized reputational information).

A human being should stand between people, not a robot. You could do something like "Alisa" [a Russian virtual assistant], but it would be impersonal. You immediately see and you know this person, you have seen them, their voice inspires you with optimism. [...] You'll do everything, even if you don thave the time.

Given the attitudes discussed above, one could assume that time bankers made useful weak ties with professionals who polished their skills to get the contact of a trusted electrician or a seamstress, and resort to their paid services if necessary. Nevertheless, my data contested this assumption. Participants were discouraged to exchange repeatedly with the same person. As far as brokers hindered autonomous linking and matched different contractors each time, the persistence of ties has been discouraged.

The coordinator was looking for performers. I could not know them at all, I meet them once, get the service and never see them again. In this regard, I think that those who wanted to provide services, but did not want to communicate, had no problems with it. This is more a question for the coordinators, how they chose the performer.

Brokers recognized the tensions raised by the limitations of distrust and the reluctance of some participants to establish friendships, and organized social gatherings in the office, or elsewhere. These events were specifically designed to implement group exchanges and stimulate networking. The events were supposed to lead to closure - at least in cliques of the most active members - and foster bonding. Tighter connections, however, led to the spread of informal practices (unpaid services, 
favors) that met resistance from the rest of the community who refused to volunteer or provide services as favors. ${ }^{2}$

Trust is essential for any organization to work. In sharing economy studies, the establishment of trust between strangers is a recurrent theme, reputation is treated as the equivalent of value [Arcidiacono, Podda 2017]. While most of the sharing-based systems take soft regulatory measures such as identity checks, peer rating evaluations, personal photo displays [Valor, Papaoikonomou 2020] and crowdsource reputational information from its users; TB rejects using an explicit evaluation system. One reason for such reluctance is that it may ruin the egalitarianism and the principles of inclusivity and justice, which provide the opportunity for all community members to exchange, not highly ranked participants alone. The downside of it, however, is the decreasing number of exchanges and reluctance to "stranger share" [Schor 2014]. Another reason is that in NNTB, the automated reputational mechanisms of the virtual platform were replaced by a human broker. Brokers play an important role in securing transactions: they scrutinize members and perform background checks; collect personal data and documentation of qualifications; do follow-ups with members and informally evaluate providers and receivers in an internal rating with a blacklist. This information is the basis for brokers' decision-making on future matching. The broker guides and navigates members' understanding of how the system works and why it works in such a manner, thus becoming a trust mediator. Generalized trust in the platform and its participants did not develop on its own, as all communication was mediated by the broker.

\section{Conclusion and discussion}

Perhaps the most recurrent theme in empirical studies of time banking is that it builds social capital by connecting private individuals in the delivering and receiving of services from one another using time currency as a medium for exchange [Collom 2008; Collom 2011; Collom 2012; Dubois et al. 2014; Seyfang 2003; Seyfang 2006]. In this paper I call this assumption into a question. The research question was: does the generation of social capital have an impact on the successful operation of a time bank? Drawing on 22 in-depth interviews with members, organizers and paid brokers in the Nizhny Novgorod Time Bank, I conclude that the TB trading economy was robust, which can explain the 15-year history of this association. However, NNTB did not conform to the ideological principles on which it was based. While providing economic value to the participants, it failed to provide social value or institutionalize as a sustainable community. The results revealed that time bankers showed great ideological alignment with the stated outcomes of participation - building community, skills (including sociability) and social networks; improved intergenerational relations; increased social inclusion for typically marginalized groups; increased access to public services. However, the practices they

\footnotetext{
2 "Here comes a newcomer. Where do they start from? They don't have hours. They can help someone. In order to help someone, they must be known. And they have to take part in events for "hours" to be known. We decided that we would give 10 hours to new arrivals. And this is what started... I remember that at times attention was focused on our personalities. And the empty talk began: "You are ruining the economy." "Strong smart people"-I call them that - started arguing for the purity of the experiment. I mean, there's been a discussion about why you're giving away 10 hours. They work for 10 hours, and we give them as a gift. Why?".
} 
followed were in conflict with these claims and did not contribute to the establishment of strong interpersonal ties. Furthermore, the brokers, who were, as results suggest, central actors in this organization, discouraged participants from establishing interpersonal ties.

TB provide a good empirical site from which to theorize about the claims of common good made by the growing field of the sharing economy. Why do we even expect such associations to generate social capital? The literature on the sharing economy grounds the expectations on the exploitation of an "innate human capacity to share" [Bird-David 2019, p. 1], as if human societies were naturally inclined to achieve cooperation, trust and togetherness. The social glue bonding the community participants together in sharing economy organizations were "sowing seeds of reciprocal obligations" [Belk 2010, p. 715]. This line of reasoning seemed self-explanatory until facing a case where it did not happen.

Sharing does not preclude calculating and self-interested behavior. Time bankers are strongly socialized as consumers in traditional marketplaces. They explicitly exhibited market-driven valuations by showing how efficient they were in translating time currency into money and vice versa. This finding challenged previous studies (e.g. [Seyfang 2001; Seyfang, Smith 2002; Seyfang 2004; Seyfang 2009; Cahn 2000; Collom 2008]) that rated the importance of alternative economic exchange behind that of the social benefits of time banking. These studies also emphasized the inclusion of services undervalued by the labor market. The results of this study revealed that in NNTB the most appreciated services were those which we use on a daily basis: educational services and small errands. Members started using NNTB for other purposes rather than stated. In her study of a Boston Time Bank, Schor found that delegation fatigue caused by anonymized and commodified versions of the services that until recently people received within the household (or, what Hochschild calls "the outsourced self" [Hochschild 2012]) was the main driver of participation [Schor 2020]. My findings barely echo the ones of Schor. The participants in my study were not fatigued in this way, as it is unlikely that they delegated the services they received in the TB. Previous studies emphasize the problem of altruism-participants deliver significantly more services than they receive - as one of the fundamental challenges that impact the high failure rates of TB [Valor, Papaoikonomou 2020; Weaver et al. 2016]. The case of NNTB showed the opposite logic: members tend to receive more services than they manage to provide to make savings for future transactions. These findings add to the hypotheses of TB's embeddedness in market logic. Previous studies in similar not-for-profit sharing economy contexts found that such practices do not necessarily lead to fostering communitarian relations, or to the improvement of social capital, but rather contribute to further individualization and the commercialization of services. Aptekar found that alternative anti-consumerist practices on Freecycle may still depend on and reflect the dominant capitalist processes and hierarchies [Aptekar 2016]. The studies of Couchsurfing revealed that this platform strengthens class hierarchies, as hosts are eager to meet "comfortably exotic" guests, i.e. of a similar social class [Ladegaard 2018; Shmidt 2020].

Sharing does not foster technocratic trust in time banking. Compared to its forprofit counterpart YouDo, an online marketplace that matches freelance labor with local demand, a TB does not generate any trust in the platform. The basic elements of trust: knowledge about past performance and belonging to a known circle are missing. The distinctive feature of a TB is that the broker who oversees and sustains operations plays the role of the mediator of trust: the role which was supposed to be taken over 
by platform algorithms with their capacity to crowdsource reputational information. Combined with the techno-pessimism of some participants and a reluctance to communicate peer-to-peer using the web-platform, this highlights the attempts to overcome the risks of dealing with strangers by appealing to more archaic rather than more high-end technology. Transforming interpersonal trust into more impersonal forms (what Putnam 1993 called social trust) is required to foster cooperation. "Voluntary cooperation is easier in a community that has inherited a substantial stock of social capital" [Putnam 1993, p. 176]. TB have not succeeded in forming such a stock. Furthermore, the norms of reciprocity, which are required for social trust to emerge, were absent from the organizational context of TB. Reciprocity might be mistaken for compensation in the context of time banking. Social capital research has noted that the generalized norm of reciprocity increases social capital among network members [Coleman 1988; Putnam 2000], time banking has been pronounced as an instance of this norm [Collom 2008]. Evidently, studies of the sharing economy appeal to this logic to imply altruistic and stabilizing neighborly values [Kennedy 2016]. Sharing, however, may not foster communal social relations because of the non-necessity of reciprocation as a situational opportunity rather than a contractual obligation towards a fixed set of partners [Widlok 2020, p. 27]. Furthermore, in time banking, the reciprocation may be erroneously taken for compensation. Reciprocity refers to the "extension of control"having agency over the future economic behavior of others or informal expectations of return [Kennedy 2016]. In time banking, the members have a degree of autonomy allowing them to enter and exit exchanges whenever they want. However, the usage of time-based currency and the prescribed double role of providers and receivers of services puts certain demands on the behavior of time bankers: there is an expectation of immediate compensation.

I sum up this discussion by placing time banking in line with similar not-for-profit sharing associations. We may find sparks of interest in different sharing models in Russia, specifically commercial ones: consumer-to-consumer online marketplaces, freelance work, and car-sharing. In the not-for-profit sector, food sharing and give-away sites have been the most institutionalized [Ekonomika sovmestnogo potrebleniya $\mathrm{v}$ Rossii 2020; Foodsharing in Russia 2019]. As long as a sharing site answers either market logic or 'gift-giving' logic, it attracts consumers socialized in the practice of balanced reciprocity typical for markets. However, at the junction of the two logics-when the largely ephemeral time becomes a calculable currency - users may experience tensions in defining the properties and norms of such exchange. The findings on the efficient translation between time and money is a paradox of time banking. Furthermore, a TB is dependent on external funding, while other sites are often self-sufficient. Previous studies provide support for this hypothesis. Parigi and State found a negative effect on social capital in not-for-profit sharing sites due to investor pressures to increase transactions and revenue which normalized asociality [Parigi et al. 2013]. Similar sharing sites functioned successfully when they had institutional support (were nested in schools, hospitals, churches, elderly care facilities, etc.) or were established in communities with high demand [Light, Miskelly 2014; Seyfang 2004].

I may hypothesize that the fundamental difference between TB and other notfor-profit sharing economy sites lies in the centrality of a broker. The necessity of a broker for the successful continuity of a TB and the dependency on external funding a broker requires suggests that this association have been organized in an environment 
that was not geared for it. While other sites distribute the moderating function to the members (fostering informal social control and autonomy), time bankers are deprived of the opportunity to govern the community together. On other sharing economy sites, the trustworthiness of counteragents is promoted by monitoring reputational information about one another, such as in Couchsurfing, Freecycling or Daru-dar (a site for sharing of consumables), while in a TB, brokers discourage members from monitoring one another or checking up on receivers and providers of services. Another distinguishing feature is that brokers in TB do not give participants the freedom of choosing the counteragent, which is common practice in other sharing contexts. Finally, in TB, there was no place for collective action, as in collaborative spaces.

\section{References}

Albinsson P.A., Yasanthi Perera B. (2012) Alternative Marketplaces in the 21st Century: Building Community through Sharing Events. Journal of Consumer Behaviour, vol. 11, no 4, pp. 303-315. DOI: $10.1002 / \mathrm{cb} .1389$

Aptekar S. (2016) Gifts among Strangers: The Social Organization of Freecycle Giving. Social Problems, vol. 63, no 2, pp. 266-283.

Arcidiacono D., Podda A. (2017) Sharing Time: New Forms of Reciprocity in the Digital Economy. Work Organisation, Labour \& Globalisation, vol. 11, no 2, pp. 39-58. DOI: 10.13169 /workorgalaboglob.11.2.0039

Arvidsson A. (2018) Value and Virtue in the Sharing Economy. The Sociological Review, vol. 66, no 2, pp. 289-301. DOI: $10.1177 / 0038026118758531$

Belk R. (2007) Why Not Share Rather Than Own? The ANNALS of the American Academy of Political and Social Science, vol. 611, no 1, pp. 126-140. DOI: $10.1177 / 0002716206298483$

Belk R. (2010) Sharing. Journal of Consumer Research, vol. 36, no 5, pp. 715-734. DOI: $10.1086 / 612649$

Belk R. (2014) You Are What You Can Access: Sharing and Collaborative Consumption Online. Journal of Business Research, vol. 67, no 8, pp. 1595-1600. DOI: $10.1016 / \mathrm{j} . j b u s r e s .2013 .10 .001$

Belk R. (2017) Sharing without Caring. Cambridge Journal of Regions, Economy and Society, vol. 10, no 2, pp. 249-261. DOI: 10.1093/cjres/rsw045

Benkler Y. (2004) Sharing Nicely: On Shareable Goods and the Emergence of Sharing as a Modality of Economic Production. The Yale Law Journal, vol. 114, no 2, p. 273. DOI: $10.2307 / 4135731$

Bird-David N. (2019) Where Have All the Kin Gone? On Hunter-Gatherers' Sharing, Kinship and Scale, McDonald Institute for Archaeological Research.

Boyle D. (2014) The Potential of Time Banks to Support Social Inclusion and Employability. JCR Scientific and Policy Reports.

Burt R.S. (2009) Structural Holes: The Social Structure of Competition, Harvard University Press.

Cahn E., Rowe J. (1992) Time Dollars: The New Currency that Enables Americans to Turn Their Hidden Resource - Time - into Personal Security \& Community Renewal, Emmaus, Pennsylvania: Rodale.

Cahn E.S. (2000) No More throw-away People: The Co-Production Imperative, Edgar Cahn.

Castiglione D., van Deth J.W., Wolleb G. (eds.) (2008) The Handbook of Social Capital, OUP Oxford.

Cockayne D.G. (2016) Sharing and Neoliberal Discourse: The Economic Function of Sharing in the Digital On-demand Economy. Geoforum, vol. 77, pp. 73-82. DOI: $10.1016 /$ j.geoforum.2016.10.005 
Coleman J.S. (1988) Social Capital in the Creation of Human Capital. American Journal of Sociology, no 94, pp. 95-120.

Collom E. (2008) Engagement of the Elderly in Time Banking: The Potential for Social Capital Generation in an Aging Society. Journal of Aging \& Social Policy, vol. 20, no 4, pp. 414-436.

Collom E. (2011) Motivations and Differential Participation in a Community Currency System: The Dynamics within a Local Social Movement Organization. Sociological Forum, vol. 26, no 1 , pp. 144-168.

Collom E. (2012) Key Indicators of Time Bank Participation: Using Transaction Data for Evaluation. International Journal of Community Currency Research, no 16(A), pp. 18-29.

Davies A.R., Donald B., Gray M., Knox-Hayes J. (2017) Sharing Economies: Moving beyond Binaries in a Digital Age. Cambridge Journal of Regions, Economy and Society, vol. 10, no 2, pp. 209-230. DOI: 10.1093/cjres/rsx005

Del Moral-Espín L. (2013) Espacios comunitarios de intercambio, bienestar y sostenibilidad de la vida: estudio de casos sobre bancos de tiempo en un contexto europeo (doctoral dissertation), Universidad Pablo de Olavide.

Del Moral L., Pais I. (2015) Collaborative Economy and the Digitalization of Timebanking: Opportunities and Challenges. Studi di Sociologia, vol. 53, no 1, pp. 3-21.

Dittmer K. (2013) Local Currencies for Purposive Degrowth? A Quality Check of Some Proposals for Changing Money-as-usual. Journal of Cleaner Production, vol. 54, pp. 3-13.

Dubois E., Schor J., Carfagna L. (2014) New Cultures of Connection in a Boston Time Bank. Sustainable Lifestyles and the Quest for Plentitude: Case Studies of the New Economy (ed. Schor J.), New Haven, CT: Yale University Press, pp. 95-124.

Eckhardt G.M., Bardhi F. (2016) The Relationship between Access Practices and Economic Systems. Journal of the Association for Consumer Research, vol. 1, no 2, pp. 210-225. DOI: $10.1086 / 684684$

Ekonomika sovmestnogo potrebleniya v Rossii [The Economy of Shared Consumption in Russia] (2020). Tiar Center, March 10, 2020. Available at: https://tiarcenter.com/sharing-report-2019/, accessed 25.06.2021.

Foodsharing in Russia (2019). Tiar Center, November 12, 2019. Available at: https://tiarcenter.com/en/foodsharing-in-russia/, accessed 25.06.2021.

Frenken K., Schor J. (2017) Putting the Sharing Economy into Perspective. Environmental Innovation and Societal Transitions, vol. 23, pp. 3-10. DOI: 10.1016/j.eist.2017.01.003

Fukuyama F. (1995) Social Capital and the Global Economy. Foreign Affairs, vol. 74, no 5, pp. 89-103.

Gawthorpe K. (2017) Which Characteristics of Communities Boost Time-banking? Case Study of the United States. International Journal of Community Currency Research, vol. 21, pp. 51-64.

Grassmuck V. (2012) The Sharing Turn: Why We Are Generally Nice and Have a Good Chance to Cooperate Our Way out of The Mess We Have Gotten Ourselves Into. Microeconomics: Welfare Economics \& Collective Decision-Making eJournal.

Harvey J., Smith A., Golightly D. (2018) Online Technology as a Driver of Sharing. The Rise of the Sharing Economy: Exploring the Challenges and Opportunities of Collaborative Consumption (eds. Albinsson P.A., Perera B.Y.), ABC-CLIO, pp. 75-96.

Henley J. (2012) Greece on the Breadline: Cashless Currency Takes off. The Guardian, March 16, 2012. Available at: https:/www.theguardian.com/world/2012/mar/16/greeceon-breadline-cashless-currency, accessed 20.06.2021.

Hochschild A.R. (2012) The Outsourced Self: Intimate Life in Market Times, Metropolitan Books.

Horowitz S. (2011) Occupy Big Business: The Sharing Economy's Quiet Revolution. The Atlantic, December 7, 2011. Available at: https://www.theatlantic.com/business/archive/2011/12/occupy-big-business-the-sharingeconomys-quiet-revolution/249582/, accessed 20.06.2021.

John N.A. (2013) Sharing and Web 2.0: The Mergence of a Keyword. New Media \& Society, vol. 15, no 2, pp. 167-182. DOI: 10.1177/1461444812450684

John N.A. (2017) The Age of Sharing, John Wiley \& Sons.

Kaplan H., Gurven M., Hill K., Hurtado A.M. (2005) The Natural History of Human Food Sharing and Cooperation: A Review and a New Multi-Individual Approach to the Negotiation 
of Norms. Moral Sentiments and Material Interests: The Foundations of Cooperation in Economic Life, vol. 6, pp. 75-113.

Kennedy J. (2016) Conceptual Boundaries of Sharing. Information, Communication \& Society, vol. 19 , no 4, pp. 461-474.

Kovács B., Morris J., Polese A., Imami D. (2017) Looking at the 'Sharing' Economies Concept through the Prism of Informality. Cambridge Journal of Regions, Economy and Society, vol. 10 , no 2 , pp. $365-378$.

Kropotkin P.A. (1902) Mutual Aid: A Factor or Evolution, McClure Phillips and Company.

Ladegaard I. (2018) Hosting the Comfortably Exotic: Cosmopolitan Aspirations in the Sharing Economy. The Sociological Review, vol. 66, no 2, pp. 381-400.

Lessig L. (2008) Remix: Making Art and Commerce Thrive in the Hybrid Economy, Penguin.

Light A., Miskelly C. (2014) Design for Sharing, Northumbria University.

Martin C.J. (2016) The Sharing Economy: A Pathway to Sustainability or a Nightmarish Form of Neoliberal Capitalism? Ecological Economics, vol. 121, pp. 149-159. DOI: 10.1016/j.ecolecon.2015.11.027

McArthur E. (2015) Many-to-many Exchange without Money: Why People Share Their Resources. Consumption Markets \& Culture, vol. 18, no 3, pp. 239-256. DOI: 10.1080/10253866.2014.987083

Mitusov M. (2013) Den'gi special'nogo naznacheniya [Special Purpose Money]. Buisnessjournal, no 6, pp. 42-48.

Morozov E. (2013) The 'Sharing Economy' Undermines Workers Rights. Financial Times, October 14, 2013. Available at: https://www.ft.com/content/92c3021c-34c2-11e3-8148-00144feab7de, accessed 20.06.2021.

North P. (2003) Time Banks-Learning the Lessons from LETS? Local Economy, vol. 18, no 3, pp. 267-270.

Onyx J., Bullen P. (2000) Measuring Social Capital in Five Communities. The Journal of Applied Behavioral Science, vol. 36, no 1, pp. 23-42.

Ostrom E. (1990) Governing the Commons: The Evolution of Institutions for Collective Action, Cambridge University Press.

Ozanne L.K., Ballantine P.W. (2010) Sharing as a Form of Anti-consumption? An Examination of Toy Library Users. Journal of Consumer Behaviour, vol. 9, no 6, pp. 485-498.

Parigi P., State B., Dakhlallah D., Corten R., Cook K. (2013) A Community of Strangers: The Dis-embedding of Social Ties. PLoS ONE, vol. 8, no 7, e67388. DOI: 10.1371 journal.pone.0067388

Price J.A. (1975) Sharing: The Integration of Intimate Economies. Anthropologica, vol. 17, no 1, pp. 3-27. DOI: $10.2307 / 25604933$

Pryor F.L., Graburn N.H. (1980) The Myth of Reciprocity. Social Exchange (eds. Gergen K.J., Greenberg M.S., Willis R.H.), Boston, MA: Springer, pp. 215-237.

Putnam R. (1993) The Prosperous Community: Social Capital and Public Life. The American Prospect, vol. 4, pp. 35-42.

Putnam R.D. (1995) Tuning In, Tuning Out: The Strange Disappearance of Social Capital in America. PS: Political Science \& Politics, vol. 28, no 4, pp. 664-684.

Putnam R.D. (2000) Bowling Alone: America's Declining Social Capital. Culture and Politics, New York: Palgrave Macmillan, pp. 223-234.

Ravenelle A.J. (2018) Hustle and Gig: Struggling and Surviving in the Sharing Economy, University of California Press.

Schor J. (2014) Debating the Sharing Economy. Great Transition Initiative, May 2, 2014. Available at: https://greattransition.org/publication/debating-the-sharing-economy, accessed 25.06.2021.

Schor J. (2020) After the Gig: How the Sharing Economy Got Hijacked and How to Win It Back, University of California Press.

Schor J.B., Cansoy M. (2019) The Sharing Economy, The Oxford Handbook of Consumption. DOI: 10.1093/oxfordhb/9780190695583.013.32

Seyfang G. (2001) Working for the Fenland Dollar: An Evaluation of Local Exchange Trading Schemes as an Informal Employment Strategy to Tackle Social Exclusion. Work, Employment and Society, vol. 15, no 3, pp. 581-593. 
Seyfang G. (2003) Growing Cohesive Communities One Favour at a Time: Social Exclusion, Active Citizenship and Time Banks. International Journal of Urban and Regional Research, vol. 27, no 3, pp. 699-706.

Seyfang G. (2004) Working outside the Box: Community Currencies, Time Banks and Social Inclusion. Journal of Social Policy, vol. 33, no 1, pp. 49-71.

Seyfang G. (2006) Harnessing the Potential of the Social Economy? Time Banks and UK Public Policy. International Journal of Sociology and Social Policy, vol. 26, no 9/10, pp. 430-443. DOI: $10.1108 / 01443330610690569$

Seyfang G. (2009) The New Economics of Sustainable Consumption, Buenos Aires: Biblos.

Seyfang G., Smith K. (2002) The Time of Our Lives: Using Time Banking for Neighbourhood Renewal and Community Capacity Building, NEF.

Shmidt M. (2020) Participants' Interaction with Sharing Economy Platforms in Russia. Information Technology \& People, vol. 33, no 3, pp. 897-917. DOI: 10.1108/ITP-10-2018-0443

Ter Huurne M., Ronteltap A., Corten R., Buskens V. (2017) Antecedents of Trust in the Sharing Economy: A Systematic Review. Journal of Consumer Behaviour, vol. 16, no 6, pp. 485-498.

Toennies F. (1957) Community and Society (original work published in 1887), New York: Harper Torchbook.

Valor C., Papaoikonomou E. (2020) Sharing Economy to the Rescue? The Case of Timebanking. Handbook of the Sharing Economy (eds. Belk R.W., Eckhardt G.M., Bardhi F.), Edward Elgar Publishing.

Weaver P., Dumitru A., García-Mira R., Lema-Blanco A., Muijsers L., Vasseur V. (2016) Transformative Social Innovation Report: Timebanking. TRANSIT: EU SSH.2013.3.2-1 Grant agreement, no: 613169.

Widlok T. (2016) Anthropology and the Economy of Sharing, London; New York: Routledge.

Widlok T. (2020) Sharing as an Alternative Economic Activity. Handbook of the Sharing Economy (eds. Belk R.W., Eckhardt G.M., Bardhi F.), Edward Elgar Publishing.

William C.C., Aldridge T., Tooke J. (2003) Alternative Exchange Spaces. Alternative Economic Spaces (eds. Lee R., Leyson A., Williams C.C.), London: Sage, pp. 151-167.

Woodburn J. (1998) Sharing Is not a Form of Exchange: An Analysis of Property Sharing in Immediate-Return Hunter-Gatherer Societies. Property Relations: Renewing the Anthropological Tradition (ed. Hann C.M.), Cambridge: Cambridge University Press, pp. 48-63.

Zykova T. (2013) Dash na Dash. Barter i denezhnye surrogaty snova v mode [Barter and Money Surrogates Are in Fashion Again]. Rossijskaya gazeta, February 26, 2013. Available at: https://rg.ru/2013/02/26/barter.html, accessed 20.06.2021.

\title{
Шеринг-экономика и социальный капитал: фиктивные ожидания социальности в Банке времени
}

\author{
М.А. ШМИДТ*
}

*Майя Андреевна Шмидт - аспирант, Департамент социологии, Уппсальский университет. Адрес: Thunbergsvägen 3Н, 75126 Уппсала, Швеция. E-mail: mayya.shmidt@soc.uu.se

Цитирование: Shmidt M. (2021) The Sharing Economy and Social Capital: The Fictional Expectations of Sociality in a Time Bank. Mir Rossii, vol. 30, no 4, pp. 128-155. DOI: 10.17323/1811-038X-2021-30-4-128-155 
В статье анализируется такое понятие, как «Банк времени» - системы безвозмездного обмена услугами, в которой «валютой» для взаимных расчетов становится время. Отличительной чертой является то, что временная денежная единица, использующаяся для обменов внутри системы, не имеет номинала. Цена «временной валюты» составляет «час труда любого человека», независимо от характера предоставляемой услуги. В литературе, посвященной таймбанкингу, он описывается как социальная инновация, ориентированная на развитие местных сообществ, особенно в неблагополучных местах и условиях. Несмотря на то, что подобные организации не отличаются большим числом участников [Gawthorpe 2017], 3аявленными целями участия в них являются укрепление слабых социальных сетей, решение проблем бедности и социальной изоляции. Более того, Банки времени способствуют развитию социального капитала и гражданского участия [North 2010], хотя большинство из них не способны институционализироваться в качестве поставщиков социальных услуг и терпят неудачу в течение первых трех лет [Weaver et al. 2016]. В предложенной статье исследуется уникальная история успеха - Банк времени в Нижнем Новгороде, существующий на протяжении 15 лет; к тому же это кейс организации, не позиционирующей себя как волонтерской и не стремящейся к созданию локального сообщества закрытого типа.

В статье был поставлен следующий исследовательский вопрос: влияет ли создание социального капитала сообществом на его успешное воспроизводство внутри экономики совместного потребления (sharing economy)? Чтобы ответить на этот вопрос, автор обращается к sharing economy studies - растущему, но неоднородному корпусу исследований. Работы в области экономики совместного потребления на сегодняшний день в основном сосредоточены на полярных кейcax: операциях между бизнесом и клиентами (b2c-платформы, например каршеринг) или низовых сообществах, практикующих альтернативы рыночному обмену. Исследования объединены предположением, что эти организации будут генерировать социальный капитал. В этой статье автор стремится проверить гипотезу и исследовать, являются ли неформальные сети, нормы взаимности и доверия, которые поощряются среди членов Банка времени, факторами, объясняющими устойчивость этой ассоциации.

Эмпирическую базу работы составляют 22 интервью, записанных на диктофон и транскрибированных verbatim. Выборка в случае интервью гетерогенна, выстроена по принципу максимальной вариации участников по уровню вовлеченности (активные участники и новички, а также организаторы: директор и методист нижегородского Банка времени, координаторы, выполняющие функцию посредников). Дополнительным источником данных служат интервью с экспертом по созданию локальных валют, а также интервью в СМИ с первым попечителем Банка времени. Рекрутинг информантов проводился через веб-сайт Банка времени, а также по принципу «снежного кома» - движением по сети социальных контактов членов Банка времени. В интервью используется гайд свободной формы. Особенное внимание уделялось следующим нарративам: (1) социально-демографическим характеристикам акторов и структуре их социального капитала; (2) характеристике режима обмена услугами (объему, направленности, репертуару услуг, соотношению с профессиональной деятельностью и другими сферами жизни); (3) ценностному набору и мировоззренческим установкам (эгалитаризму, альтруизму, справедливости); (4) степени обобщенного доверия. 
Результаты показали, что участники Банка времени не склонны создавать прочные и устойчивые отношения вне рамок обмена. В статье выдвигается следующая объяснительная гипотеза: калькулятивность участников, рыночная оценка «эгалитарного» обмена услугами и одностороннее отношение к обмену вступают в конфликт со стремлением к созданию сообщества типа Gemeinschaft с сильной взаимозависимостью, основанной на нормах взаимности. В то же время эта ассоциация не обеспечивает условий для возникновения обобщенного доверия. Стремясь воссоздать тесно связанное сообщество, но отвечающее потребностям цифровой эпохи, организация столкнулась с технопессимизмом участников, не готовых использовать платформенные механизмы создания репутации.

Помимо рассматриваемого случая, исследование теоретизирует риторику и реальность экономики совместного использования, обобщая основания ожиданий создания социального капитала, и объясняет, почему определенные ожидания не могут быть выполнены.

Ключевые слова: Банки времени, экономика совместного потребления, некоммерческие ассоциации, социальный капитал, доверие, посредничество

\section{Литература}

Зыкова Т. (2013) Дашь на дашь. Бартер и денежные суррогаты снова в моде // Российская газета. 26 февраля 2013 // https://rg.ru/2013/02/26/barter.html

Митусов М. (2013) Деньги специального назначения // Бизнес- журнал. № 6. С. 42-48.

Экономика современного потребления в России (2020) // Tiar Center. 10 марта 2020 // https://tiarcenter.com/sharing-report-2019/

Albinsson P.A., Yasanthi Perera B. (2012) Alternative Marketplaces in the 21st Century: Building Community through Sharing Events // Journal of Consumer Behaviour, vol. 11, no 4, pp. 303-315. DOI: $10.1002 / \mathrm{cb} .1389$

Aptekar S. (2016) Gifts among Strangers: The Social Organization of Freecycle Giving // Social Problems, vol. 63, no 2, pp. 266-283.

Arcidiacono D., Podda A. (2017) Sharing Time: New Forms of Reciprocity in the Digital Economy // Work Organisation, Labour \& Globalisation, vol. 11, no 2, pp. 39-58. DOI: $10.13169 /$ workorgalaboglob.11.2.0039

Arvidsson A. (2018) Value and Virtue in the Sharing Economy // The Sociological Review, vol. 66, no 2, pp. 289-301. DOI: 10.1177/0038026118758531

Belk R. (2007) Why Not Share Rather Than Own? // The ANNALS of the American Academy of Political and Social Science, vol. 611, no 1,pp. 126-140. DOI: 10.1177/0002716206298483

Belk R. (2010) Sharing // Journal of Consumer Research, vol. 36, no 5, pp. 715-734. DOI: $10.1086 / 612649$

Belk R. (2014) You Are What You Can Access: Sharing and Collaborative Consumption Online // Journal of Business Research, vol. 67, no 8, pp. 1595-1600. DOI: 10.1016/j.jbusres.2013.10.001

Belk R. (2017) Sharing without Caring // Cambridge Journal of Regions, Economy and Society, vol. 10, no 2, pp. 249-261. DOI: 10.1093/cjres/rsw045

Benkler Y. (2004) Sharing Nicely: On Shareable Goods and the Emergence of Sharing as a Modality of Economic Production // The Yale Law Journal, vol. 114, no 2, p. 273. DOI: $10.2307 / 4135731$ 
Bird-David N. (2019) Where Have All the Kin Gone? On Hunter-Gatherers' Sharing, Kinship and Scale, McDonald Institute for Archaeological Research.

Boyle D. (2014) The Potential of Time Banks to Support Social Inclusion and Employability // JCR Scientific and Policy Reports.

Burt R.S. (2009) Structural Holes: The Social Structure of Competition, Harvard University Press.

Cahn E., Rowe J. (1992) Time Dollars: The New Currency that Enables Americans to Turn Their Hidden Resource - Time - into Personal Security \& Community Renewal, Emmaus, Pennsylvania: Rodale.

Cahn E.S. (2000) No More throw-away People: The Co-Production Imperative, Edgar Cahn.

Castiglione D., van Deth J.W., Wolleb G. (eds.) (2008) The Handbook of Social Capital, OUP Oxford.

Cockayne D.G. (2016) Sharing and Neoliberal Discourse: The Economic Function of Sharing in the Digital On-demand Economy // Geoforum, vol. 77, pp. 73-82. DOI: 10.1016/j.geoforum.2016.10.005

Coleman J.S. (1988) Social Capital in the Creation of Human Capital // American Journal of Sociology, no 94, pp. 95-120.

Collom E. (2008) Engagement of the Elderly in Time Banking: The Potential for Social Capital Generation in an Aging Society // Journal of Aging \& Social Policy, vol. 20, no 4, pp. 414-436.

Collom E. (2011) Motivations and Differential Participation in a Community Currency System: The Dynamics within a Local Social Movement Organization // Sociological Forum, vol. 26, no 1, pp. 144-168.

Collom E. (2012) Key Indicators of Time Bank Participation: Using Transaction Data for Evaluation // International Journal of Community Currency Research, no 16(A), pp. 18-29.

Davies A.R., Donald B., Gray M., Knox-Hayes J. (2017) Sharing Economies: Moving beyond Binaries in a Digital Age // Cambridge Journal of Regions, Economy and Society, vol. 10, no 2, pp. 209-230. DOI: 10.1093/cjres/rsx005

Del Moral-Espín L. (2013) Espacios comunitarios de intercambio, bienestar y sostenibilidad de la vida: estudio de casos sobre bancos de tiempo en un contexto europeo (doctoral dissertation), Universidad Pablo de Olavide.

Del Moral L., Pais I. (2015) Collaborative Economy and the Digitalization of Timebanking: Opportunities and Challenges // Studi di Sociologia, vol. 53, no 1, pp. 3-21.

Dittmer K. (2013) Local Currencies for Purposive Degrowth? A Quality Check of Some Proposals for Changing Money-as-usual // Journal of Cleaner Production, vol. 54, pp. 3-13.

Dubois E., Schor J., Carfagna L. (2014) New Cultures of Connection in a Boston Time Bank // Sustainable Lifestyles and the Quest for Plentitude: Case Studies of the New Economy (ed. Schor J.), New Haven, CT: Yale University Press, pp. 95-124.

Eckhardt G.M., Bardhi F. (2016) The Relationship between Access Practices and Economic Systems // Journal of the Association for Consumer Research, vol. 1, no 2, pp. 210-225. DOI: $10.1086 / 684684$

Foodsharing in Russia (2019) // Tiar Center, November 12, 2019 // https://tiarcenter.com/en/foodsharing-in-russia/

Frenken K., Schor J. (2017) Putting the Sharing Economy into Perspective // Environmental Innovation and Societal Transitions, vol. 23, pp. 3-10. DOI: $10.1016 /$ j.eist.2017.01.003

Fukuyama F. (1995) Social Capital and the Global Economy // Foreign Affairs, vol. 74, no 5, pp. 89-103.

Gawthorpe K. (2017) Which Characteristics of Communities Boost Time-banking? Case Study of the United States // International Journal of Community Currency Research, vol. 21, pp. $51-64$.

Grassmuck V. (2012) The Sharing Turn: Why We Are Generally Nice and Have a Good Chance to Cooperate Our Way out of The Mess We Have Gotten Ourselves Into // Microeconomics: Welfare Economics \& Collective Decision-Making eJournal.

Harvey J., Smith A., Golightly D. (2018) Online Technology as a Driver of Sharing // The Rise of the Sharing Economy: Exploring the Challenges and Opportunities of Collaborative Consumption (eds. Albinsson P.A., Perera B.Y.), ABC-CLIO, pp. 75-96. 
$\begin{gathered}\text { Henley J. (2012) Greece on the Breadline: } \\ \text { The }\end{gathered}$ Cashless
Guardian, Currency Takes off $/ /$ https://www.theguardian.com/world/2012/mar/16/greece-on-breadline-cashless-currency

Hochschild A.R. (2012) The Outsourced Self: Intimate Life in Market Times, Metropolitan Books.

Horowitz S. (2011) Occupy Big Business: The Sharing Economy's Quiet Revolution // The Atlantic, December 7, $2011 / /$ https://www.theatlantic.com/business/archive/2011/12/ occupy-big-business-the-sharing-economys-quiet-revolution/249582/

John N.A. (2013) Sharing and Web 2.0: The Mergence of a Keyword // New Media \& Society, vol. 15 , no 2, pp. 167-182. DOI: $10.1177 / 1461444812450684$

John N.A. (2017) The Age of Sharing, John Wiley \& Sons.

Kaplan H., Gurven M., Hill K., Hurtado A.M. (2005) The Natural History of Human Food Sharing and Cooperation: A Review and a New Multi-Individual Approach to the Negotiation of Norms // Moral Sentiments and Material Interests: The Foundations of Cooperation in Economic Life, vol. 6, pp. 75-113.

Kennedy J. (2016) Conceptual Boundaries of Sharing // Information, Communication \& Society, vol. 19 , no 4, pp. 461-474.

Kovács B., Morris J., Polese A., Imami D. (2017) Looking at the 'Sharing' Economies Concept through the Prism of Informality // Cambridge Journal of Regions, Economy and Society, vol. 10, no 2, pp. 365-378.

Kropotkin P.A. (1902) Mutual Aid: A Factor or Evolution, McClure Phillips and Company.

Ladegaard I. (2018) Hosting the Comfortably Exotic: Cosmopolitan Aspirations in the Sharing Economy // The Sociological Review, vol. 66, no 2, pp. 381-400.

Lessig L. (2008) Remix: Making Art and Commerce Thrive in the Hybrid Economy, Penguin.

Light A., Miskelly C. (2014) Design for Sharing, Northumbria University.

Martin C.J. (2016) The Sharing Economy: A Pathway to Sustainability or a Nightmarish Form of Neoliberal Capitalism? // Ecological Economics, vol. 121, pp. 149-159. DOI: 10.1016/j.ecolecon.2015.11.027

McArthur E. (2015) Many-to-many Exchange without Money: Why People Share Their Resources // Consumption Markets \& Culture, vol. 18, no 3, pp. 239-256. DOI: $10.1080 / 10253866.2014 .987083$

Morozov E. (2013) The 'Sharing Economy' Undermines Workers Rights // Financial Times, October 14, 2013 // https://www.ft.com/content/92c3021c-34c2-11e3-8148-00144feab7de

North P. (2003) Time Banks-Learning the Lessons from LETS? // Local Economy, vol. 18, no 3 , pp. $267-270$.

Onyx J., Bullen P. (2000) Measuring Social Capital in Five Communities // The Journal of Applied Behavioral Science, vol. 36, no 1, pp. 23-42.

Ostrom E. (1990) Governing the Commons: The Evolution of Institutions for Collective Action, Cambridge University Press.

Ozanne L.K., Ballantine P.W. (2010) Sharing as a Form of Anti-consumption? An Examination of Toy Library Users // Journal of Consumer Behaviour, vol. 9, no 6, pp. 485-498.

Parigi P., State B., Dakhlallah D., Corten R., Cook K. (2013) A Community of Strangers: The Dis-embedding of Social Ties // PLoS ONE, vol. 8, no 7, e67388. DOI: 10.1371 /journal.pone. 0067388

Price J.A. (1975) Sharing: The Integration of Intimate Economies // Anthropologica, vol. 17, no 1, pp. 3-27. DOI: $10.2307 / 25604933$

Pryor F.L., Graburn N.H. (1980) The Myth of Reciprocity // Social Exchange (eds. Gergen K.J., Greenberg M.S., Willis R.H.), Boston, MA: Springer, pp. 215-237.

Putnam R. (1993) The Prosperous Community: Social Capital and Public Life // The American Prospect, vol. 4, pp. 35-42.

Putnam R.D. (1995) Tuning In, Tuning Out: The Strange Disappearance of Social Capital in America // PS: Political Science \& Politics, vol. 28, no 4, pp. 664-684.

Putnam R.D. (2000) Bowling Alone: America's Declining Social Capital // Culture and Politics, New York: Palgrave Macmillan, pp. 223-234. 
Ravenelle A.J. (2018) Hustle and Gig: Struggling and Surviving in the Sharing Economy, University of California Press.

Schor J. (2014) Debating the Sharing Economy // Great Transition Initiative, May 2, 2014 // https:/greattransition.org/publication/debating-the-sharing-economy

Schor J. (2020) After the Gig: How the Sharing Economy Got Hijacked and How to Win It Back, University of California Press.

Schor J.B., Cansoy M. (2019) The Sharing Economy, The Oxford Handbook of Consumption. DOI: 10.1093/oxfordhb/9780190695583.013.32

Seyfang G. (2001) Working for the Fenland Dollar: An Evaluation of Local Exchange Trading Schemes as an Informal Employment Strategy to Tackle Social Exclusion // Work, Employment and Society, vol. 15, no 3, pp. 581-593.

Seyfang G. (2003) Growing Cohesive Communities One Favour at a Time: Social Exclusion, Active Citizenship and Time Banks // International Journal of Urban and Regional Research, vol. 27, no 3, pp. 699-706.

Seyfang G. (2004) Working outside the Box: Community Currencies, Time Banks and Social Inclusion // Journal of Social Policy, vol. 33, no 1, pp. 49-71.

Seyfang G. (2006) Harnessing the Potential of the Social Economy? Time Banks and UK Public Policy // International Journal of Sociology and Social Policy, vol. 26, no 9/10, pp. 430-443. DOI: 10.1108/01443330610690569

Seyfang G. (2009) The New Economics of Sustainable Consumption, Buenos Aires: Biblos.

Seyfang G., Smith K. (2002) The Time of Our Lives: Using Time Banking for Neighbourhood Renewal and Community Capacity Building, NEF.

ShmidtM. (2020) Participants'Interaction with Sharing Economy Platforms in Russia// Information Technology \& People, vol. 33, no 3, pp. 897-917. DOI: 10.1108/ITP-10-2018-0443

Ter Huurne M., Ronteltap A., Corten R., Buskens V. (2017) Antecedents of Trust in the Sharing Economy: A Systematic Review // Journal of Consumer Behaviour, vol. 16, no 6, pp. 485-498.

Toennies F. (1957) Community and Society (original work published in 1887), New York: Harper Torchbook.

Valor C., Papaoikonomou E. (2020) Sharing Economy to the Rescue? The Case of Timebanking // Handbook of the Sharing Economy (eds. Belk R.W., Eckhardt G.M., Bardhi F.), Edward Elgar Publishing.

Weaver P., Dumitru A., García-Mira R., Lema-Blanco A., Muijsers L., Vasseur V. (2016) Transformative Social Innovation Report: Timebanking. TRANSIT: EU SSH.2013.3.2-1 Grant agreement, no: 613169.

Widlok T. (2016) Anthropology and the Economy of Sharing, London; New York: Routledge.

Widlok T. (2020) Sharing as an Alternative Economic Activity // Handbook of the Sharing Economy (eds. Belk R.W., Eckhardt G.M., Bardhi F.), Edward Elgar Publishing.

William C.C., Aldridge T., Tooke J. (2003) Alternative Exchange Spaces // Alternative Economic Spaces (eds. Lee R., Leyson A., Williams C.C.), London: Sage, pp. 151-167.

Woodburn J. (1998) Sharing Is not a Form of Exchange: An Analysis of Property Sharing in Immediate-Return Hunter-Gatherer Societies // Property Relations: Renewing the Anthropological Tradition (ed. Hann C.M.), Cambridge: Cambridge University Press, pp. 48-63. 